\title{
UJI COBA MUTU BIBIT MERANTI MERAH DI HPH PT ERNA JULIAWATI KALIMANTAN TENGAH
}

\author{
Experiment Test on Seedling Quality of Red Meranti in Forest Concession Holder \\ PT Erna Juliawati, Centre Kalimantan
}

\author{
R. Mulyana Omon \\ Balai Penelitian dan Pengembangan Teknologi Perbenihan (BP2TP) Bogor \\ Jalan Pakuan Ciheuluet Po. Box 105 Bogor \\ Telp. (0251) 8327768
}

Naskah masuk : 28 Sepember; Naskah diterima : 17 September 2010

\begin{abstract}
A study on seedling quality of two red meranti species was conducted at IUPHHK PT Erna Juliawati in Central Kalimantan. The purpose of this study was to provides information on seedling quality of two red meranti species one year after planting in the field. The seedling of both species which was treated until 7 months were selected based on Standarisasi Nasional Indonesia (SNI 01-5005.1-1999) before planting in the field that is quality class of height, diameter and value strength. The treatments consisted of two species (Shorea leprosula and Shorea parvifolia) and three seedlings quality class from wilding. The experimental design used factorial in a randomized complete block design with 4 replications. Each treatment consisted of 100 plants were planted with $20 \times 2.5 \mathrm{~m}$ spacing. The total numbers of plants observed were 2400 plants. The survival, height and diameter of seedlings were measured to evaluate the growth of both species one year after planting in the field. The results showed that species, interaction between species and seedlings quality were not significantly affect the survival rate, while the block and seedling quality gave significant effect on survival rate. The growth of height was significantly affected by block, species, interaction between species and seedling quality. However, differences in diameter growth at one year after planting are only affected by the block. The Tukey test showed that the survival rate of both species in block II between seedling quality one and the other quality were significantly different (88.8\% and $84.3 \%$, respectively), while the height and diameter growth of both species in block III were higher compared in the other block. Meanwhile, S. parvifolia from seedling quality one achieved an average height of $184.6 \mathrm{~cm}$ higher than that other interaction between species and seedling quality. Therefore S. parvifolia from wilding with seedling quality one with height ranged $50 \mathrm{~cm} 65 \mathrm{~cm}$ and diameter ranged $5 \mathrm{~mm}-8 \mathrm{~mm}$ is recommended as a standard of quality seedlings for planting in Silin program with Selective Cutting and Planted Indonesia Intensive System.
\end{abstract}

\section{Keywords: Growth, red meranti, seedling quality class, wilding}

\begin{abstract}
ABSTRAK
Penelitian uji coba mutu bibit dua jenis meranti merah telah dilakukan di areal IUPHHK PT Erna Juliawati, Kalimantan Tengah. Tujuan penelitian ini adalah untuk menyediakan informasi mutu bibit dua jenis meranti merah setelah satu tahun ditanam di lapangan. Bibit yang telah dipelihara selama tujuh bulan di persemaian, sebelum ditanam di lapangan diseleksi terlebih dahulu berdasarkan Standarisasi Nasional Indonesia (SNI 01-5005.1-1999) yaitu berdasarkan kriteria tinggi dan diameter bibit serta nilai kekokohan bibit. Perlakuan terdiri dari dua jenis meranti merah dan tiga mutu bibit asal cabutan. Rancangan percobaan yang digunakan adalah faktorial dalam pola acak lengkap berblok yang diulang sebanyak 4 kali. Setiap perlakuan ditanam sebanyak 100 tanaman dengan jarak tanam 20 x 2,5 m. Jumlah tanaman yang diamati sebanyak 2.400 bibit. Parameter bibit yang diuji adalah persen hidup dan pertumbuhan (tinggi dan diameter). Hasil penelitian menunjukkan bahwa perlakuan jenis, mutu bibit, interaksi antara jenis dan mutu bibit tidak berpengaruh nyata terhadap persen hidup, namun block dan mutu bibit berpengaruh nyata terhadap persen hidup, sedangkan. untuk pertumbuhan (tinggi dan diameter) hanya blok yang berpengaruh nyata. Berdasarkan uji beda nyata Tukey menujukkan bahwa
\end{abstract}


persen hidup bibit untuk ke dua jenis meranti pada blok II antara mutu bibit satu dengan mutu bibit yang lainnya berpengaruh nyata yaitu $88,8 \%$ and $84,3 \%$. Pertumbuhan tinggi dan diameter bibit pada blok III untuk kedua jenis meranti lebih tinggi dibandingkan pada blok lainnya, sementara untuk S. parvifolia. yang berasal dari mutu bibit satu lebih tinggi dibandingkan dengan interaksi antara jenis dan mutu bibit lainnya, yaitu sebesar 184,6 cm. Dengan demikian jenis $S$. parvifolia dari cabutan dengan mutu bibit satu, yaitu tinggi antara $(50-65 \mathrm{~cm})$ atau rata-rata sebesar $59,3 \mathrm{~cm}$ dengan diameter antara $(5-8 \mathrm{~mm})$ atau ratarata sebesar $5,8 \mathrm{~mm}$ dapat dijadikan standard mutu bibit untuk ditanam dalam program silin dengan sistem TPTI Intensif.

\section{Kata kunci : cabutan, kelas mutu bibit, meranti merah, pertumbuhan}

\section{PENDAHULUAN}

Meranti merah (red meranti) adalah salah jenis dari suku Dipterocarpaceae yang kayunya bernilai ekonomi tinggi dan beberapa jenis mempunyai pertumbuhan yang cukup cepat. Soekotjo (2007) melaporkan bahwa ada lima jenis meranti merah yang menunjukkan pertumbuhan yang cukup cepat. Salah satu contohnya adalah uji coba tiga (3) jenis Shorea yang telah berumur 4,5 tahun di PT Sari Bumi Kusuma yang menunjukkan hasil rata-rata riap diameter per tahun masing-masing jenis untuk Shorea leprosula sebesar $1,8 \mathrm{~cm} / \mathrm{th}, S$. parvifolia sebesar $2,1 \mathrm{~cm} / \mathrm{th}, S$. platyclados sebesar 2,5 $\mathrm{cm} / \mathrm{th}, S$. johorensis sebesar $2,2 \mathrm{~cm} / \mathrm{tahun}$ dan $S$. macrophylla sebesar $1,6 \mathrm{~cm} / \mathrm{th}$.

Untuk memperoleh pertumbuhan tanaman yang baik di lapangan harus didukung oleh pemilihan bibit dengan kualitas baik, agar tegakan yang dihasilkan baik. Dalam rangka usaha mendapatkan bibit yang bermutu diperlukan penilaian mutu bibit sesuai standard. Standardisasi mutu bibit Dipterorapaceae dapat dilakukan melalui pembuatan kriteria mutu bibit yang terukur dan bersifat kuantitatif dan dapat pula didasarkan pada fenotipe bibit karena mudah diukur dan dapat dianggap sebagai gambaran genetik. Zobel dan Talbert (1984) menjelaskan bahwa ciri atau sifat yang sering ditampilkan setiap individu tidak lepas dari pengaruh lingkungan dan genetik. Apabila kualitas fenotipe baik maka kita mengetahui bahwa individu tersebut memiliki potensi genetik untuk tumbuh baik (Schmidt, 2000).

Mutu bibit ditentukan oleh dua faktor, yaitu faktor dalam dan faktor luar. Faktor dalam diantaranya asal benih, kondisi fisik dan fisiologis benih atau kondisi fisik dan fisiologis bibit itu sendiri. Faktor luar yang penting antara lain air, cahaya, suhu, kelembaban udara, konsentrasi karbon dioksida, oksigen, pupuk, jenis medium bibit, mikoriza, hama, penyakit dan gulma di persemaian (Hendromono, 2007).
Penelitian uji coba mutu bibit ini mengacu pada Standar Nasional Indonesia jenis Meranti (SNI 01-5005.1-1999) yang berdasarkan pengujian di persemaian. Oleh karena itu perlu dilakukan uji coba di lapangan sampai dengan umur satu tahun.

Tujuan dari penelitian ini adalah menyediakan informasi mengenai uji coba yang terukur dan praktis terhadap pertumbuhan bibit dua (2) jenis meranti dengan mutu bibit sesuai kriteria SNI 01-5005.1-1999). Hasil penelitian ini diharapkan dapat menjadi bahan untuk melengkapi penyusunan Standarisasi Nasional Indonesia untuk kedua jenis tersebut.

\section{BAHAN DAN METODE}

\section{A. Lokasi dan Waktu Penelitian}

Penelitian ini dilakukan di Izin Usaha Pengelolaaan Hasil Hutan Kayu (IUPHHK) No. 15/Kpts-IV/19999 PT Erna Juliawati Kalimantan Tengah, luas 184.206 Ha. Secara administrasi pemerintahan lokasi PT Erna Juliawati termasuk Kecamatan Tumbang Manjul, Kabupaten Seruyan, Propinsi Kalimantan Tengah. Lokasi pembuatan petak coba penelitian terletak di petak HH 39 Blok I RKT 2008.

Penanaman dilakukan pada bulan Juni 2008, kemudian dilakukan pengamatan setelah enam bulan penanaman pada bulan Desember 2008 dan duabelas bulan setelah penanaman pada bulan Juni 2009.

\section{B. Tanah dan Iklim}

Jenis tanah di IUPHHK, PT Erna Juliwati termasuk jenis Podsolik Merah Kuning sebesar $56 \%$ dan sebesar $44 \%$ termasuk jenis latosol berdasarkan peta tanah pulau Kalimantan skala 1:1.000.000 dari Pusat Penelitian Tanah dan Agroklimat (1993). Menurut Klasifikasi Iklim Schmidt dan Ferguson (1951) ke dua lokasi 
termasuk tipe Iklim A dengan rata-rata curah hujan $3.559 \mathrm{~mm} / \operatorname{tahun~dan~hari~hujan~} 238$ hari.

\section{Bahan dan Alat Penelitian}

\section{Bahan}

Bahan yang digunakan terdiri dari :

Bibit dari dua jenis bibit meranti merah $(S$. leprosula dan S. parvifolia) yang berasal dari cabutan dan telah dipelihara selama tujuh bulan di persemaian. Cabutan diambil di sekitar pohon plus, sehingga dapat dianggap sebagai bibit yang bermutu. Sebelum penanaman bibit diklasifikasi berdasarkan tiga kelas mutu bibit yang telah tersedia (SNI 01-5005.1-1999) ditambah dengan satu kelas mutu bibit dibawahnnya, yaitu yang tinggi $<$ $35 \mathrm{~cm}$ dan diameter $<4,0 \mathrm{~mm}$, seperti disajikan pada Tabel 1.

Media yang digunakan di persemaian adalah tanah bagian atas (top soil).

Tabel (Table) 1. Kriteria mutu bibit dipterocarpaceae (Criteria of dipterocarps seedling quality)

\begin{tabular}{|c|c|c|c|c|}
\hline No & $\begin{array}{l}\text { Kriteria penilaian (valuation } \\
\text { criteria) }\end{array}$ & $\begin{array}{l}\text { Mutu bibit satu } \\
\text { (seedling quality } \\
\text { one) }\end{array}$ & $\begin{array}{l}\text { Mutu bibit dua } \\
\text { (seedling quality } \\
\text { two) }\end{array}$ & $\begin{array}{l}\text { Mutu bibit tiga } \\
\text { (seedling quality } \\
\text { three) }\end{array}$ \\
\hline 1. & $\begin{array}{l}\text { Kekompakan media (media } \\
\text { compaction) }\end{array}$ & - & - & - \\
\hline 2. & Tinggi (height) & $50-65 \mathrm{~cm}$ & $35-49 \mathrm{~cm}$ & $35<$ \\
\hline 3. & Diameter (diameter) & $5,0-8,0 \mathrm{~mm}$ & $4,0-4,9 \mathrm{~mm}$ & $4,0<$ \\
\hline 4. & $\begin{array}{l}\text { Nilai kekokohan bibit } \\
\text { (strength value of seedling) }\end{array}$ & $6,3-10,8$ & $8,8-12,0$ & - \\
\hline 5. & Pucuk / akar (top root ratio) & - & - & - \\
\hline 6. & $\begin{array}{l}\text { Persentase kolonisasi } \\
\text { mikoriza (Percentage of } \\
\text { mycorrhizae colonisasion) }\end{array}$ & - & - & - \\
\hline
\end{tabular}

\section{Alat}

Peralatan lapangan yang digunakan dalam penelitian seperti meteran, kaliper, mistar dan kamera.

\section{Rancangan Percobaan}

Rancangan yang digunakan adalah Rancangan Acak Kelompok Faktorial 2 x 3. Faktor A adalah jenis yang terdiri dari 2 jenis yaitu $S$. leprosula (A1) dan $S$. parvifolia (A2). Faktor B adalah kelas mutu bibit yang terdiri dari 3 kelas yaitu kelas mutu bibit satu (B1), kelas mutu bibit dua (B2) dan kelas mutu bibit tiga (B3). Masing-masing perlakuan diulang sebanyak 4 kali dan setiap ulangan menggunakan 100 bibit, sehingga jumlah bibit yang digunakan adalah $2 \times 3 \times 4 \times 100=2.400$ bibit.

Penanaman disesuaikan dengan kegiatan penanaman operasional di IUPHHK PT Erna Juliawati. Penanaman dilakukan sistem jalur yang disesuaikan dengan pedoman TPTII, yaitu lebar jalur 3 meter, jarak antara jalur $20 \mathrm{~m}$ dan jarak tanam didalam jalur $2,5 \mathrm{~m}$. Luas areal penanaman adalah $2,5 \times 20 \times 2.400=120.000 \mathrm{~m}^{2}$ atau seluas 12 ha.

\section{Penanaman}

Sebelum penanaman dilakukan terlebih dahulu dilakukan penyiapan lahan sesuai dengan pedoman teknis sistem Tebang Pilih Tanam Indonesia Intensif (TPTII). Kegiatan penyiapan lahan meliputi pembersihan jalur, pemasangan ajir, pembuatan lubang tanam kemudian penanaman. Pembersihan jalur dilakukan dengan membersihkan jalur penanaman dari vegetasi lain selebar $3 \mathrm{~m}$ vertikal baik secara manual maupun mekanis. Lubang tanam berukuran $40 \times 40 \mathrm{~cm}$ dengan kedalaman $30 \mathrm{~cm}$ dan diisi dengan bagian atas tanah (top soil) yang diambil dari lokasi sekitarnya.

Penanaman dilakukan dengan sistem jalur dimana jarak antar jalur $20 \mathrm{~m}$ dan jarak tanam antar tanaman di dalam jalur 2,5 m. Masingmasing jalur memiliki lebar $3 \mathrm{~m}$ dan panjang 250 m. Pemeliharaan tanaman dilakukan sesuai dengan petunjuk teknis sistem TPTII, tetapi tidak dilakukan penyulaman dengan maksud untuk melihat kemampuan bibit tersebut di lapangan. 


\section{E. Pengumpulan Data}

\section{Di persemaian}

Untuk data penunjang kualitas mutu bibit telah dilakukan penilaian terhadap nilai kekokohan, nisbah batang akar (top root ratio) dan kekompakan media pada waktu penanaman (pada waktu merobok kantong plastik/polybag tidak media terjadi pecah/utuh). Penilaian kekokohan bibit dan nisbah batang akar, kolonisasi akar bermikoriza pada setiap kelas mutu bibit diambil masing-masing 10 bibit sebagai contoh untuk setiap jenis.

Kekokohan bibit dihitung sebagai nisbah antara tinggi bibit $(\mathrm{cm})$ dengan diameter $(\mathrm{mm})$ (Jayusman, 2005) dan nilai nisbah batang akar ditentukan berdasarkan pengukuran yang dihitung sebagai nisbah antara tinggi bibit $(\mathrm{cm})$ dengan panjang akar (cm). Perhitungan kolonisasi akar yang bermikoriza di hitung dengan menggunakan alat mikroskop terhadap akar yang terinfeksi dan tidak terinfeksi fungi mikoriza di laboratorium Balai Penelitian Teknologi Perbenihan Samboja.

\section{Di lapangan}

Pengamatan dilakukan pada waktu enam (6) dan dua belas (12) bulan setelah penanaman. Parameter yang diamati adalah tinggi, diameter dan persen hidup tanaman. Tinggi tanaman diukur dari pangkal hingga ujung tanaman dengan menggunakan meteran. Diameter tanaman diukur pada ketinggian $10 \mathrm{~cm}$ dari permukaan tanah dengan alat ukur kaliper.

\section{E. Analisa Data}

Parameter yang dianalisis adalah persen hidup dan pertambahan tinggi dan diameter di lapangan. Analisis data yang digunakan adalah analisis sidik ragam (ANOVA). Apabila terdapat perbedaan nyata antar perlakuan dilanjutkan dengan uji lanjutan yaitu uji beda nyata Tukey (Haeruman, 1975).

\section{HASIL DAN PEMBAHASAN}

\section{A. Persentase Hidup}

Berdasarkan dari hasil sidik ragam menunjukkan bahwa perlakuan jenis, mutu bibit, interaksi antara jenis dan mutu bibit tidak menunjukkan pengaruh yang nyata terhadap persentase hidup tanaman, kecuali blok setelah berumur enam bulan di lapangan. Akan tetapi setelah satu tahun di tanam blok dan mutu bibit menunjukkan perbedaan yang nyata, seperti disajikan pada Tabel 2 dan 3 .

Tabel(Table) 2. Rata-rata hasil uji beda nyata Tukey blok terhadap perentase hidup jenis meranti merah setelah enam dan satu tahun ditanam di lapangan (Average results of significant different test of Tukey on block to survival rate of red meranti species after six months and one year planted in the field)

\begin{tabular}{|c|c|c|c|}
\hline \multicolumn{2}{|c|}{ Umur enam bulan ( six months old) } & \multicolumn{2}{c|}{ Umur dua belas bulan (twelve months old) } \\
\hline $\begin{array}{c}\text { Blok } \\
\text { block })\end{array}$ & $\begin{array}{c}\text { Rata-rata persentase hidup } \\
\text { (average survival rate) } \%\end{array}$ & $\begin{array}{c}\text { Blok } \\
\text { (block) }\end{array}$ & $\begin{array}{c}\text { Rata-rata persentase hidup (average } \\
\text { survival rate) } \%\end{array}$ \\
\hline IV & $87,8 \mathrm{a}$ & IV & $74,2 \mathrm{a}$ \\
\hline I & $88,8 \mathrm{a}$ & I & $79,8 \mathrm{~b}$ \\
\hline III & $90,8 \mathrm{ab}$ & III & $80,7 \mathrm{~b}$ \\
\hline II & $96,5 \mathrm{~b}$ & II & $88,8 \mathrm{c}$ \\
\hline $\begin{array}{c}\text { Rataan } \\
\text { average })\end{array}$ & 90,6 & $\begin{array}{c}\text { Rataan } \\
\text { (average })\end{array}$ & 80,5 \\
\hline
\end{tabular}

Keterangan (Remarks): Nilai rata-rata yang diikuti oleh hurup berbeda menunjukkan perbedaan yang nyata pada tingkat $5 \%$ berdasarkan uji beda nyata Tukey (Mean values followed by different letters are significanly different at 5\% level based on Tukey significant different test)

Tabel 2 menunjukkan rataan persen hidup secara keseluruhan dari kedua jenis tanaman meranti merah mengalami penurunan dari periode pengamatan enam bulan sampai dengan satu tahun setelah penanam yaitu rata-rata sebesar $10 \%$. Penurunan persen hidup pada awal penanaman diakibatkan karena penurunan kualitas bibit waktu proses pengangkutan bibit dari persemaian ke tempat penanaman dan proses adaptasi dengan lingkungan. Daniel et al. (1979) melaporkan bahwa beberapa faktor lingkungan yang dapat penyebabkan kematian bibit setelah 
penanaman, yaitu intensitas cahaya, iklim mikro, lantai hutan, tanaman pesaing, tanah dan faktor biotis. Jika dilihat persen hidup dari setiap jenis dan kelas mutu bibit cukup baik yaitu lebih dari $75 \%$. Daryadi dan Harjono (1972) melaporkan dengan besar persentase hidup tersebut selama satu tahun ditanam dikatagorikan cukup baik. Ditambah lagi pada saat penanaman selama satu tahun tersebut tidak dilakukan penyulaman, tetapi hanya pemeliharaan sesuai dengan pedoman teknis TPTII. Maksud tidak dilakukannya penyulaman setelah tiga bulan ditanam adalah untuk melihat kemampuan hidup dari masing-masing jenis dan kelas mutu bibit selama satu tahun ditanam di lapangan.

Berdasarkan hasil uji Tukey (Tabel 2) memperlihatkan persen hidup paling tinggi, yaitu yang ditanam di blok II sebesar 88,8 \% dibandingkan blok I sebesar 79,8 \%, blok III sebesar $80,7 \%$ dan blok IV sebesar 74,2 \% setelah satu tahun ditanam. Rendahnya persen hidup di blok IV dan I, dikarenakan pada waktu penanaman, kondisi di blok I dan IV terdapat beberapa jalur penanaman terletak di bekas jalan sarad yang sangat terbuka. Kondisi yang terlalu terbuka ini yang menyebabkan terjadinya kematian tanaman. Oleh karena itu untuk jenis $S$. leprosula dan S. parvifolia merupakan jenis yang membutuhkan setengah naungan pada waktu muda dan selanjutnya membutuhkan cahaya penuh untuk pertumbuhannya (Mok, 1993). Priadjati (2003) menyatakan bahwa S. leprosula merupakan jenis yang memerlukan cahaya pada tahap awal pertumbuhan $60-70 \%$ (intensitas cahaya relatif) untuk semai dan $74-100 \%$ untuk tingkat pancang.

Tabel 3 menunjukkan persen hidup untuk kelas mutu bibit tiga paling rendah dan berbeda nyata dibandingkan dengan kelas mutu satu dan dua yaitu masing-masing sebesar 84,3\%, 82,1\% dan 76,3\% Rendahnya persen hidup untuk kelas mutu bibit tiga dikarenakan ukuran bibit kecil, yaitu tinggi $<35 \mathrm{~cm}$ dan diamerter $<4 \mathrm{~mm}$ dibandingkan kelas mutu bibit satu dan dua. Hal ini ternyata bahwa bibit berukuran kecil berpengaruh terhadap daya tahan tanaman pada saat pengangkutan dan setelah penanaman di lapangan. Bibit tersebut belum siap bersaing dengan tumbuhan lain disekitarnya dan kurang tahan terhadap proses pengangkutan, sehingga mengakibatkan kematian setelah ditanam di lapangan.

Tabel(Table) 3. Rata-rata hasil uji beda nyata Tukey mutu bibit terhadap persentase hidup jenis meranti merah setelah satu tahun ditanam di lapangan (Average results of significant different test of Tukey seedling quality to survival rate of red meranti species after one year planted in the field)

\begin{tabular}{|c|l|c|}
\hline No & \multicolumn{1}{|c|}{$\begin{array}{c}\text { Perlakuan mutu bibit } \\
\text { (seedling quality treatments) }\end{array}$} & $\begin{array}{c}\text { Rata-rata persentase hidup } \\
\text { (average survival rate) } \%\end{array}$ \\
\hline 1 & B3=Mutu bibit tiga (seedling quality three) & $76,3 \mathrm{a}$ \\
\hline 2 & B2=Mutu bibit dua (seedling quality two) & $82,1 \mathrm{~b}$ \\
\hline 3 & B1= Mutu bibit satu (seedling quality one) & $84,3 \mathrm{~b}$ \\
\hline
\end{tabular}

Ketengan (Remarks): B1 = mutu bibit satu (seedling quality one), B2 = mutu bibit dua (seedling quality two), B3=mutu bibit tiga (seedling quality three).

Nilai rata-rata yang diikuti oleh hurup berbeda menunjukkan perbedaan yang nyata pada tingkat $5 \%$ berdasarkan uji beda nyata Tukey (Mean values followed by different letters are significanly different at $5 \%$ level based on Tukey significant different test).

\section{B. Pertambahan Tinggi dan Diameter}

Dari hasil analisis keragaman blok, jenis dan interaksi antara jenis dan mutu bibit telah menunjukkan pengaruh yang nyata terhadap pertambahan tinggi (riap tinggi) setelah satu tahun ditanam di lapangan. Untuk pertumbuhan diameter, hanya blok yang berpengaruh nyata terhadap pertumbuhan diameter. Untuk mengetahui interaksi antara jenis dan mutu bibit serta blok mana, yang riap lebih tinggi setelah satu tahun ditanam di lapangan telah dilakukan uji beda nyata Tukey, seperti disajikan pada Tabel 4 dan 5.

Hasil uji beda nyata Tukey (Tabel 4) setelah satu tahun ditanam menunjukkan riap tinggi dan diameter yang di tanam di blok III dan IV tidak berbeda nyata yaitu masing-masing sebesar 179,7 cm, 177,3 cm dan 165,8 cm. Untuk diameter masing-masing sebesar $2,6 \mathrm{~cm}$ dan $2,6 \mathrm{~cm}$. Tidak berbeda nyatanya pertumbuhan tinggi dan diameter di kedua blok setelah satu tahun ditanam, terlihat lingkungannya di kedua 
blok hampir sama. Hal ini dikarenakan oleh tegakan tinggal antara jalur setelah satu tahun telah tertutup kembali oleh permudaan alam yang dapat mengembalikan iklim mikro di lantai hutan.

Berdasarkan Tabel 5 bahwa jenis $S$. parvifolia dari mutu bibit satu memperlihatkan riap tinggi yang paling tinggi dibandingkan dengan kombinasi lainnya, yaitu sebesar 184,6 $\mathrm{cm}$. Akan tetapi tidak berbeda nyata dengan jenis S. leprosula dari mutu bibit tiga dan S. parvifolia dari mutu bibit tiga. Walaupun kelas mutu bibit 3 memiliki rata-rata pertumbuhan yang tinggi, akan tetapi rata-rata tinggi tanaman tidak melebihi kelas mutu bibit satu dan dua.
Tidak berbeda pertumbuhan tinggi kedua jenis tersebut setelah satu tahun ditanam di lapangan, begitu pula yang terjadi di PT Sari Bumi Kusumah berdasarkan hasil uji jenis riap untuk jenis $S$. leprosula dan $S$. parvifolia masing-masing hampir sama yaitu sebesar 221,2 cm dan 224,6 cm (Soekotjo, 2007). Kedua jenis meranti merah ini termasuk dalam jenis setengah toleran, walaupun membutuhkan naungan pada awalnya, tetapi untuk pertumbuhan selanjutnya memerlukan cahaya. Yassir dan Mitikauji (2007) melaporkan bahwa pertumbuhan tanaman sangat dipengaruhi oleh interaksi ketiga faktor, yaitu faktor keturunan (genetik), lingkungan dan teknik silvikultur.

Tabel (Table) 4. Rata-rata hasil uji beda nyata Tukey blok terhadap riap tinggi dan diameter jenis meranti merah setelah enam dan satu tahun ditanam di lapangan (Average results of significant different test of Tukey on block to height and diameter growth of red meranti species after six month and one year planted in the field)

\begin{tabular}{|c|c|c|c|c|}
\hline \multicolumn{3}{|c|}{ Umur enam bulan (six months old) } & \multicolumn{2}{|c|}{ Umur dua belas bulan (tweleve months old) } \\
\hline $\begin{array}{c}\text { Blok } \\
\text { (block) }\end{array}$ & $\begin{array}{c}\text { Rata-rata riap tinggi } \\
\text { (average height } \\
\text { growth) } \mathrm{cm}\end{array}$ & $\begin{array}{c}\text { Riap diameter } \\
\text { (average } \\
\text { diameter } \\
\text { growth) } \mathrm{cm}\end{array}$ & $\begin{array}{c}\text { Rata-rata riap tinggi } \\
\text { (average height } \\
\text { growth) cm }\end{array}$ & $\begin{array}{c}\text { Riap diameter } \\
\text { (average diameter } \\
\text { growth) } \mathrm{cm}\end{array}$ \\
\hline I & $42,8 \mathrm{a}$ & $0,2 \mathrm{a}$ & $141,7 \mathrm{a}$ & $2,0 \mathrm{a}$ \\
\hline II & $47,6 \mathrm{ab}$ & $0,3 \mathrm{a}$ & $165,8 \mathrm{~b}$ & $2.3 \mathrm{~b}$ \\
\hline III & $55,2 \mathrm{bc}$ & $0,4 \mathrm{c}$ & $177,3 \mathrm{~b}$ & $2,6 \mathrm{c}$ \\
\hline IV & $58,4 \mathrm{c}$ & $0,5 \mathrm{c}$ & $179,7 \mathrm{~b}$ & $2,6 \mathrm{c}$ \\
\hline
\end{tabular}

Keterangan(Remarks): Nilai rata-rata yang diikuti oleh huruf berbeda menunjukkan perbedaan yang nyata pada tingkat $5 \%$ berdasarkan uji beda nyata Tukey (Mean values followed by different letters are significanly different at $5 \%$ level based on Tukey significant different test)

Tabel(Table) 5. Rata-rata hasil uji beda nyata Tukey interaksi antara jenis dan mutu bibit terhadap pertambahan tinggi (riap) jenis meranti merah setelah satu tahun ditanam di lapangan (Average results of significant different test of Tukey interaction between species seedling quality to height growthh of red meranti species after one year planted in the field)

\begin{tabular}{|c|c|c|}
\hline No. & $\begin{array}{c}\text { Perlakuan interaksi antara jenis dan mutu bibit (Interaction } \\
\text { between species and seedling quality treatments })\end{array}$ & $\begin{array}{c}\text { Rata-rata riap tinggi } \\
\text { (average height growth) } \mathrm{cm}\end{array}$ \\
\hline 1 & Interaksi antara A1 dan B1 (Interaction between A1 and B1) & $143,8 \mathrm{a}$ \\
\hline 2 & Interaksi antara A1 dan B2 (Interaction between A1 and B2) & $162,2 \mathrm{ab}$ \\
\hline 3 & Interaksi antara A2 dan B2 (Interaction between A2 and B2) & $163,3 \mathrm{~b}$ \\
\hline 4 & Interaksi antara A2 dan B3 (Interaction between A2 and B3) & $169,4 \mathrm{~b}$ \\
\hline 5 & Interaksi antara A1 dan B3 (Interaction between A1 and B3) & $173,7 \mathrm{~b}$ \\
\hline 6 & Interaksi antara A2 dan B1 (Interaction between A12and B1) & $184,6 \mathrm{~b}$ \\
\hline
\end{tabular}

Ketengan(Remarks): A1 = S. leprosula, $\mathrm{A} 2=$ S. parvifolia $; \mathrm{B} 1=$ mutu bibit satu (seedling quality one), $\mathrm{B} 2=$ mutu bibit dua (seedling quality two), B3 = mutu bibit tiga (seedling quality three), B1 = mutu bibit satu (seedling quality one).

Nilai rata-rata yang diikuti oleh hurup berbeda menunjukkan perbedaan yang nyata pada tingkat $5 \%$ berdasarkan uji beda nyata Tukey (Mean values followed by different letters are significanly different at $5 \%$ level based on Tukey significant different test). 


\section{Kekokohan bibit, nisbah tinggi dan akar (top root ratio), kekompakan media dan Kolinisasi mikoriza}

Dalam penentuan mutu (kualitas) bibit selain pertumbuhan tinggi dan diameter juga indikator lainnya, yaitu nilai kekokohan, nisbah tinggi dan akar (top root ratio), kekompakan media dan kolonisasi mikoriza pada saat ditanam. Indikator ini sangat penting untuk menunjang kualitas bibit sebelum ditanam di lapangan. Berdasarkan hasil pengukuran dan penilaian rata dari kriteria dan indikator tersebut disajikan pada Tabel 6.

Jayusman (2005) melaporkan bahwa nilai kekokohan bibit dan nisbah tinggi dan akar (top root ratio) sebelum bibit ditanam adalah karakter penunjang yang sering dipakai untuk menilai sifat morfologis bibit di persemaian. Kekokohan bibit menggambarkan keseimbangan pertumbuhan antara tinggi dan diameter bibit di lapangan. Nilai kekokohan yang tinggi akan menunjukkan kemampuan hidup yang rendah karena tidak seimbang perbandingan tinggi bibit dengan diameternya. Nilai kekokohan bibit di persemaian berkisar antara 6,3 - 10,8 dikelompokkan baik (SNI 01-5005.1-1999). Dari hasil perhitungan rata-rata kekokohan bibit meranti merah jenis $S$. parvifolia dari bibit yang berasal dari cabutan yang dipelihara selama tujuh bulan di persemaian dengan nilai kekokohan sebesar 10,6 dan untuk S. leprosula sebesar 9,5 dalam katogari yang baik. Sedangkan untuk top root ratio makin kecil top root ratio akan menunjukkan pertumbuhan kurang baik. Nilai top ratio yang baik berkisar antara termasuk dalam kelompokkan baik (SNI 01-5005.1-1999). Berdasarkan hasil penilaian top ratio dari penelitian rata-rata sebesar 4,7 untuk jenis S. parvifolia diikatakan cukup baik.

Tabel(Table) 6. Hasil penilaian kriteria mutu bibit jenis S. leprosula sebelum di lakukan penanaman di lapangan (Valuation result of seedling quality criteria to $\mathrm{S}$. leprosula before planting in the field)

\begin{tabular}{|c|c|c|c|c|c|}
\hline \multirow[t]{2}{*}{$\begin{array}{c}\text { Jenis } \\
\text { (species) }\end{array}$} & \multirow{2}{*}{$\begin{array}{c}\text { Media tumbuh } \\
\text { (growth media) } \\
\begin{array}{c}\text { Bagian atas tanah } \\
(\text { top-soil })\end{array}\end{array}$} & \multirow[t]{2}{*}{$\begin{array}{l}\text { Kriteria penilaian } \\
\text { (valuation criteria) }\end{array}$} & \multicolumn{3}{|c|}{$\begin{array}{c}\text { Kelas mutu bibit (seedling quality } \\
\text { class) }\end{array}$} \\
\hline & & & $\mathrm{B} 1$ & $\mathrm{~B} 2$ & B3 \\
\hline \multirow[t]{5}{*}{ S. leprosula } & & $\begin{array}{l}\text { Kekompakan media (media } \\
\text { compaction) }\end{array}$ & utuh & utuh & Utuh \\
\hline & & $\begin{array}{l}\text { Nilai kekokohan (strength value of } \\
\text { seedling) }\end{array}$ & 9,5 & 9,8 & 9,6 \\
\hline & & $\begin{array}{l}\text { Nisbah tinggi dan akar (top root } \\
\text { ratio) }\end{array}$ & 3,6 & 3,5 & 2,4 \\
\hline & & $\begin{array}{l}\text { Persentase kolonisasi mikoriza } \\
\text { (Percentage of mycorrhizae } \\
\text { colonisation) }\end{array}$ & $65,75 \%$ & $65,62 \%$ & $59,08 \%$ \\
\hline & & $\begin{array}{l}\text { Persentase kolonisasi mikoriza } \\
\text { (Percentage of mycorrhizae } \\
\text { colonisation) }\end{array}$ & $65,7 \%$ & $65,6 \%$ & $59,1 \%$ \\
\hline \multirow[t]{4}{*}{ S. parvifolia } & & $\begin{array}{l}\text { Kekompakan media (media } \\
\text { compaction) }\end{array}$ & utuh & utuh & utuh \\
\hline & & Nilai kekokohan & 10,6 & 10,6 & 9,1 \\
\hline & & $\begin{array}{l}\text { Nisbah tinggi dan akar (top root } \\
\text { ratio) }\end{array}$ & 4,7 & 4,2 & 2,7 \\
\hline & & $\begin{array}{l}\text { Persentase kolonisasi mikoriza } \\
\text { (Percentage of mycorrhizae } \\
\text { colonisation) }\end{array}$ & $65,7 \%$ & $57,5 \%$ & $62,8 \%$ \\
\hline
\end{tabular}

Keterangan : $\mathrm{B}_{1}=$ kelas mutu bibit `satu, $\mathrm{B}_{2}=$ kelas mutu bibit kelas dua, $\mathrm{B}_{3}=$ kelas mutu bibit tiga 
Hal yang tidak kalah pentingnya bagi pertumbuhan bibit di persemaian adalah media yang digunakan. Berdasarkan hasil pengamatan di lapangan media tumbuh dengan top-soil cukup baik, yaitu pada waktu penanaman bibit ke lubang tanam tidak terjadi kerusakan artinya antara tanah dan akar melekat (utuh). Akan tetapi yang menjadi kendala apabila media tumbuh bibit mengandalkan top-soil dikhawatirkan akan terjadi kerusakan tanah hutan. Oleh karena pada saat ini di IUPHHK seperti PT SBK dan PT SARPATIN telah menggunakan kompos buatan yang terbuat dari kayu telah lapuk kemudian diracik menjadi kompos ada juga vegetasi tumbuhan bawah yang diracik dengan alat pencincang rumput kemudian ditambah M4 untuk dijadikan kompos. Kompos tersebut dicampur dengan top soil dengan perbandingan $1: 3(\mathrm{v} / \mathrm{v})$.

Berdasarkan uraian di atas dapat dinyatakan bahwa standar mutu bibit yang telah di tersedia untuk jenis meranti (SNI 01-500511999), yaitu kelas mutu satu dan dua dapat digunakan sebagai bahan acuan untuk penanaman bibit operasional di lapangan dalam program silvikultur intens 7 , khususnya dari jenis $S$. leprosula dan S. parvifolia dengan bibit yang berasal dari cabutan.

\section{KESIMPULAN DAN SARAN}

\section{A. Kesimpulan}

1. Kelas mutu bibit satu dan tanaman di blok tiga memberikan persen hidup lebih tinggi dibandingkan dengan kelas mutu bibit dan blok lainya masing-masing sebesar 84,3\% dan $88,8 \%$.

2. Kelas mutu bibit satu dari jenis Shorea parvifolia telah memberikan riap tinggi paling tinggi dibandingkan interaksi antara kelas mutu dan jenis lainnya, yaitu sebesar 184,6 $\mathrm{cm}$. Tetapi jenis meranti yang ditanam blok empat telah memberikan riap diameter yang paling tinggi dibandingkan blok lainnya, yaitu sebesar $2,61 \mathrm{~cm}$.

3. Rata-rata nilai kekokohan bibit dan nilai nisbi tinggi dan akar (top root ratio) kelas mutu bibit satu yang baik sebagai penunjang untuk penentuan kualitas (mutu) bibit untuk ditanam di lapangan, yang masing-masing 10,6 dan 4,7 dengan persen kolonisasi mikoriza sebesar $65,7 \%$.
4. Media bagian atas tanah (top soil) pada waktu penanaman utuh atau kompak, sehingga akar bibit tidak rusak.

5. Standard Nasional Indonesia (SNI 01-500511999) untuk jenis meranti dapat digunakan sebagai standar mutu bibit untuk jenis S. leprosula dan S. parvifolia.

\section{B. Saran}

Perlu juga dilakukan uji coba bibit jenis dipterokarpa lainnya dengan bibit berasal dari cabutan atau benih dengan media campuran antara kompos dan top soil

\section{DAFTAR PUSTAKA}

Daniel, T.W., J.A. Helms. dan F.S. Baker. 1979. Prinsip-prinsip silvikultur. Gadjah Mada University Press. Yogyakarta.

Haeruman, H. 1975. Prosedur analisa rancangan percobaan. bagian pertama. Bagian Perentjanaan Hutan. Departemen Mangemen Hutan, Fakultas Kehutanan, IPB, Bogor. $78 \mathrm{~h}$.

Hendromomo, 2007. Bibit berkualitas`sebagai kunci pembuka keberhasilan hutan tanaman dan rehabilitasi. Orasi Pengukuhan Profesor Riset Bidang Pengembangan Silvikultur. Badan Litbang Kehutanan, Departemen Kehutanan. Tidak diterbitkan.

Jayusman. 2005. Evaluasi keragaman genetik bibit surian di persemaian. Wana Benih Vol. 7 No. 1. Pusat Penelitian dan Pengembangan Hutan Tanaman. Yogyakarta.

Mok, S.T. 1993. Current research on artificial regeneration of Dipterocarps. FORSPA Publication 8. Forestry Research Support Program for Asia \& The Pacific (FORSPA). Kuala Lumpur. Malaysia.

Priadjati, A. 2003. Dipterocarpaceae : Forest fire and forest recovery. Tropenbos International. The Tropenbos Foundation. Wageningen. The Netherlands.

Schmidt, F.H dan J.H. Ferguson. 1951. Rainfall types based on dry and wet period ratios for Indonesia with Western New Guinea. Verhandelingen No. 42. Jawatan Meteorologi dan Geofisika, Jakarta. 
Standard Nasional Indonesia (SNI) 01-5005.11999. Standardisasi mutu bibit jenis meranti. Badan Standardisasi National, Jakarta

Schmidt, L. 2000. Pedoman penanganan benih tanaman hutan tropis dan sub tropis. Terjemahan Direktorat Jenderal Rehabilitasi Lahan dan Perhutanan Sosial, Departemen Kehutanan. Jakarta.

Soekotjo. 2007. Pengalaman dari uji jenis dipterokarpa umur 4,5 tahun di PT Sari Bumi Kusuma Kalimantan Tengah. Prosiding Seminar Pengembangan Hutan Tanaman Dipterokarpa dan Ekspose
TPTII/Silin. Balai Besar Penelitian Dipterokarpa. Samarinda.

Yassir, I. dan Y. Mitikauji. 2007. Pengaruh penyiapan lahan terhadap pertumbuhan Shorea leprosula Miq. dan Shorea balangeran (Korth.) Burck pada lahan alang-alang di Samboja, Kalimantan Timur. Jurnal Penelitian Dipterokarpa. Vol. 1 No. 1, September 2007. Balai Besar Penelitian Dipterocarpaceae. Samarinda.

Zobel, B. and J. Talbert. 1984. Applied forest tree improvement. John Wiley and Sons.Inc. New York. 